\section{A Development of Optical Network Unit Power CONSUMPTION MODEL CONSIDERING TRAFFIC LOAD EFFECT}

Arnidza Ramli*, Nadiatulhuda Zulkifli, Auwalu Usman, Sevia Mahdaliza Idrus

Lightwave Communication Research Group, Fakulti Kejuruteraan Elektrik, Universiti Teknologi Malaysia, 81310 UTM Johor Bahru, Johor, Malaysia
Article history

Received

22 December 2016

Received in revised form

29 November 2017

Accepted

15 February 2018

Published online

3 June 2018

*Corresponding author arnidza@fke.utm.my

\section{Graphical abstract}

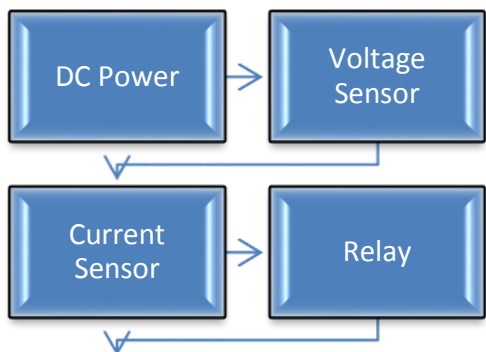

Monitored Device (ONU)

\begin{abstract}
Accurate and precise measurement of energy consumption for the deployment of fiber-to-thehome (FTTH) network using Gigabit passive optical network (GPON) is vital to the research community to develop models for the synthesis of energy-efficient protocols and algorithms for the access network. However, lack of power consumption measurement of optical network devices in the past has led to unrealistic and/or oversimplified model being used in simulations. Usually the access network devices are assumed always on and their consumption is both traffic and time independent. Therefore, in this paper we propose an experimentally-driven approach to i) characterize the Optical Network Unit (ONU) from the power consumption standpoint and ii) develop more accurate power consumption model for the ONU. We focus on ONU since it represents the main contributor to the energy consumption of optical access network. The real data in terms of the power consumption and traffic load have been obtained from continuous measurements performed on a GPON network testbed. The measurement is limited to a maximum $100 \mathrm{Mbps}$ data rate due to a limitation in the sampling rate and precision of the measurement device. However, validation has been done with theoretical power consumption model in order to prove the feasibility of the proposed model. Our measurements show that the power consumption of the ONU exhibits a linear dependence on the traffic in which the power consumption at idle mode is $11.51 \mathrm{~W}$ while in low power mode the power consumption is around $7.52 \mathrm{~W}$.

Keywords: Optical network unit, power consumption, GPON, energy efficient, testbed
\end{abstract}

\begin{abstract}
Abstrak
Pengukuran penggunaan tenaga yang tepat dan jitu untuk penggunaan rangkaian fiber-to-thehome (FTTH) menggunakan rangkaian gigabit pasif optik (GPON) adalah penting bagi komunit penyelidik untuk membina model bagi protokol dan algoritma kecekapan tenaga yang sintesis untuk rangkaian capaian. Walaubagaimanapun, kekurangan pengukuran penggunaan kuasa peranti rangkaian optik pasa masa lalu telah mendorong kepada penggunaan model yang tidak realistik dan/atau terlalu dipermudahkan di dalam simulasi. Selalunya peranti rangkaian capaian adalah diandaikan sentiasa bekerja dan penggunaan kuasa adalah tidak bergantung kepada kedua-dua trafik dan masa. Oleh itu, di dalam kertas kerja ini kami mencadangkan pendekatan ujikaji untuk i) mencirikan ONU dari sudut pandangan penggunaan kuasa dan ii) membina model penggunaan kuasa yang lebih tepat bagi ONU. Kami fokus kepada ONU disebabkan ia penyumbang utama di dalam pengunaan tenaga rangkaian capaian optik. Data-data sebenar dalam terma penggunaan kuasa dan beban trafik telah didapati melalui pengukuran berterusan yang dijalankan ke atas testbed rangkaian GPON. Pengukuran dihadkan kepada kadar data maksimum $100 \mathrm{Mbps}$ disebabkan oleh pembatasan kadar pensampelan dan kejituan alat pengukuran. Walaubagaimanapun, pengesahan telah dilakukan dengan model penggunaan kuasa teori bagi membuktikan kebolehgunaan model yang dicadangkan. Pengukuran kami menunjukkan bahawa penggunaan kuasa oleh ONU mempamerkan pergantungan yang linear ke atas trafik di mana penggunaan kuasa ketika mod idle adalah $11.51 \mathrm{~W}$ manakala ketika mod kuasa rendah adalah $7.52 \mathrm{~W}$.
\end{abstract}

Kata kunci: Unit rangkaian optik, penggunaan kuasa, GPON, kecekapan tenaga, testbed 


\subsection{INTRODUCTION}

The energy consumption footprint of Information and Communication Technology (ICT) in 2012 was $4.7 \%$ of electricity worldwide amounting to approximately 920TWh [1]. This numbers are expected to grow for the next decade due to the increase in both number of users and bandwidth hungry applications or services. The introduction of optical access network technology is highly promising as it is the most energy efficient access network technology that is capable of providing high capacity broadband access network at low bit error rate (BER) [2], [3]. However, data reveals a large expenditure of energy at optical access network due to the large presence of optical network units (ONUs) which account for approximately $60-80 \%$ energy consumed by the optical access [4]-[6] and this energy consumption is mainly due to the network usage [7].

The device power consumption is further shaped by the chosen access technology and its architecture (due to the scaling of access network by number of users connected to the network), broadband infrastructure (due to the broadband technology itself and various active components in home networks) and contribution from cooling and power supply of the facilities [8]. Although power consumed by one ONU is small (around $7 \mathrm{~W}$ to $17 \mathrm{~W}$ ), the total power consumption is huge given that there are more than 10 million ONUs installed [9].

In order to migrate toward the new green technologies generation, it is important to first define the power consumption trends of the ONU which is the largest contributor on energy consumed by optical access network. Generally, it is assumed that there is small influence of the traffic load variations on the power consumption of ONU. As a result, the power consumption of optical access network is usually defined as power per user/subscriber. However, it will be of great importance to have an accurate knowledge on the energy consumption of ONU and the effect of the traffic load on the instantaneous ONU power consumption for i) energy consumption reduction and ii) energy efficiency quantification of the network. Based on these motivating factors, the main objective of this work is to experimentally measure and analyze the power consumption patterns of the ONU by utilizing a real Gigabit Passive Optical Network (GPON) testbed. The findings from the measurements will give an insight into the network behavior paving the way to the development of more realistic model for power consumption in optical access network.

Basically, the energy models reported in the literature can be classified into three different types; theoretical models, analytic models and empirical models. The detail description on these models can be found in [10]. However, in passive optical network (PON), most of the reported works found in the literature used analytical approach in the modeling of the energy consumption. The power consumption is modeled by first defining the generic structure of different equipment located at both network provider and user premises, i.e. Optical Line Teriminal (OLT) and ONU. Then, the power consumption per network elements is calculated based on the consumption values of the defined generic structure. Various terms or classification have been found in the literature on defining the generic structure of both optical network elements. Basically, the structure of OLT and ONU consists of three modules known as an optical transceiver, signal processing (e.g. System on Chip (SoC) and memory) and interfaces.

Energy consumption measurements of optical access devices have rarely been performed in the past. Some studies on access networks assumed that access network devices are always on and their consumption is both traffic and time independent [11], [12]. On the contrary, previous studies have shown numerous works on energy consumption measurement of wireless access devices [13]-[16]. These studies have shown that the power consumption of wireless access devices have a linear relationship with traffic load. Additionally, in [16], the authors have also observed that the power consumption is monotonically increasing with the traffic load until it reaches a saturation point in which saturation means the traffic load is higher than the physical link data rate.

However, there are some recent studies that have reported on power consumption modeling of the ONU. These works are mainly presented the power consumption modeling based on analytical approach [6], [17]-[19]. Nevertheless, these works rely on a large database of devices and components in order to estimate the power consumption at functional blocks in which these values are sometimes oversimplified and do not represents current power consumption trend. In contrast, our work will experimentally measure the power consumption of the ONU with the main objective is to investigate the relationship between instantaneous ONU power consumption and access data rate.

\subsection{METHODOLOGY}

In this section, we will describe the network setups and the methodology used in order to evaluate the power consumption of the ONU. We implemented an Arduino-based power monitoring prototype to evaluate the power consumption of ONU under different traffic generation rate. The total power consumption of the monitored device is obtained through USB interface between the Arduino microcontroller and the Arduino IDE.

\subsection{GPON Network Setting}

The network is composed of a GPON network which includes the OLT, ONU and passive splitter, a personal computer (PC) and a laptop as illustrated in Figure 1. 
A PC is used as a server on the network and another laptop is used as a client in the network. The testbed is deployed at Photonics Characterization Laboratory in the Faculty of Electrical Engineering, Universiti Teknologi Malaysia. The OLT and ONU are a commercially available Corecess S204 OLT and CC3542-B ONU respectively. As shown in the configuration the client is allocated with $100 \mathrm{Mbps}$ Internet service subscriptions and is connected to the ONU as a gateway. Arduino-based power meter was utilized to provide real time power consumption monitoring of the ONU.

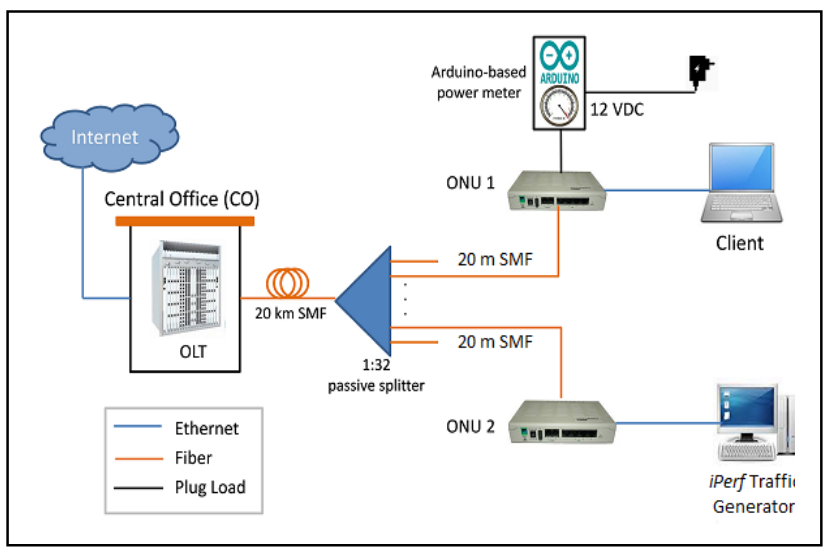

Figure 1 Network configuration used for measurement

\subsection{Traffic Generation}

Traffic is injected into the network through either the Server or the Client by using iPerf traffic generator [20]. It is an open-source software which can runs on various platforms such as Linux, Unix and Windows. iPerf is a network testing tool that can create Transmission Control Protocol (TCP) and User Datagram Protocol (UDP) data stream and measure the throughput of the network that is carrying them. Users are able to set various parameters that can be used for testing a network, or alternatively for optimizing or tuning a network. In our study, we injected a UDP traffic into the GPON network with the aim to measure the power consumption with realtime data flow when the ONU is acting as a receiver.

\subsection{Power Consumption Monitoring}

The total power consumption of the monitored device is obtained through USB interface between the Arduino microcontroller and the Arduino IDE. The statistics for the energy consumed by the ONU is collected with a granularity of $2 \mathrm{~mW}$ and sampling period of $100 \mathrm{~ms}$. It is important to remark that the power consumption measured includes the power consumed by the transceiver to process the downstream and upstream signals from the OLT and the power used by the processing board to buffer the packets and the power consumed by the Ethernet port and other peripherals.
The experimental measurement conducted in this paper is aimed at assessing the power consumption of ONU under different data rates operating at a maximum rate of $100 \mathrm{Mbps}$, even though the $\mathrm{ONU}$ is capable of supporting data rates up to 1.24 Gbps for upstream and $2.4 \mathrm{Gbps}$ for downstream. This is due to the limitation in the sampling rate and precision of the developed Arduino-based power monitoring tool. The traffic injected into the network is a UDP flow with datagram size $1470 \mathrm{kB}$, results obtained is collected during the period of 100 seconds with an interval of 10 seconds per traffic injected into the network.

\subsection{RESULTS AND DISCUSSION}

In this experiment, the iPerf injected a synthetic traffic into the network which was modeled as single UDP flows. The measurements were conducted in average of 4 runs in which each run comprises of average of measurement collected during 100 seconds. The results are reported in terms of $95 \%$ confidence interval. The complete experimental setup is depicted in Figure 2. To the best of our knowledge, this is the first such power consumption measurements presented for the ONU by using the real GPON testbed.

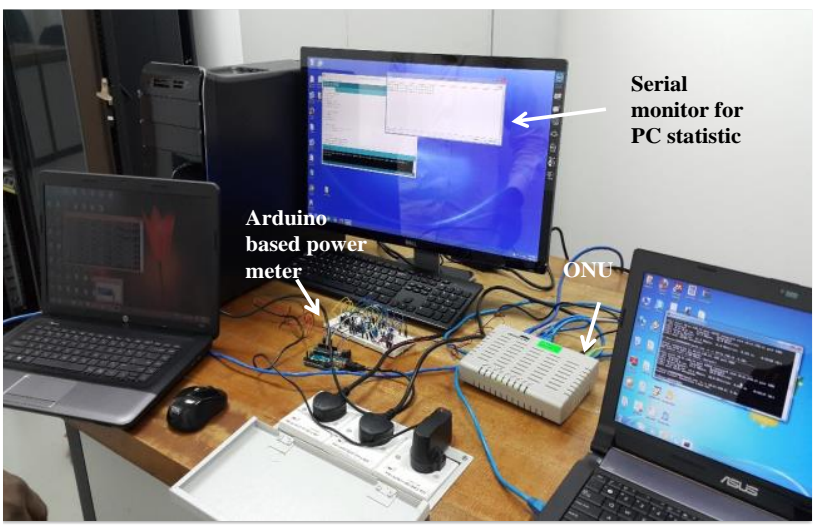

Figure 2 Experimental setup for measuring power consumption of ONU using GPON testbed

The experimental measurement was conducted with variations of access data rate up to $100 \mathrm{Mbps}$ when the ONU is acting as a receiver. The power consumption for ONU without any data injected into the network i.e. in idle mode has been measured and is around $11.51 \mathrm{~W}$ while in low power mode the power consumption is around $7.52 \mathrm{~W}$. The power consumption measurement was plotted as a function of data rates as shown in Figure 3. 


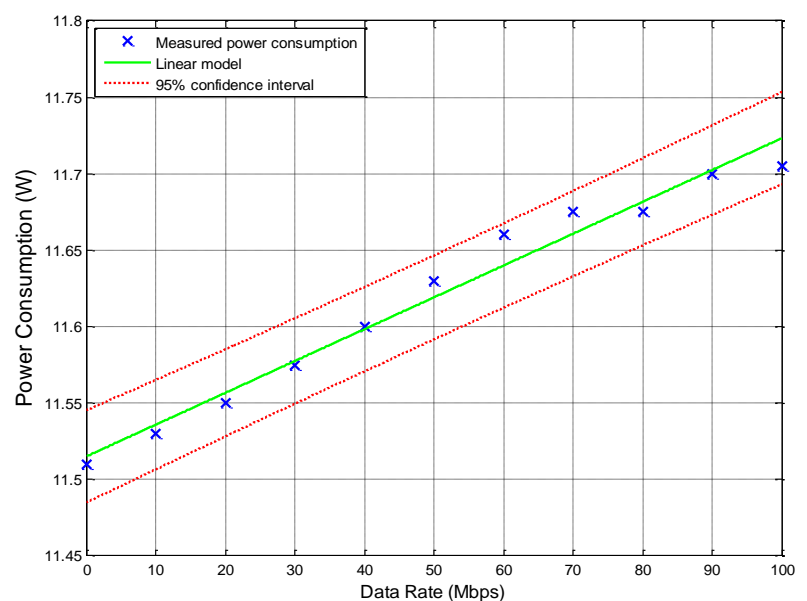

Figure 3 Power consumption of ONU versus access data rate

Figure 3 presents the measurement of the mean power consumption of the ONU when a single end user device transmitted UDP data traffic. Results are shown of power consumption as the access data rate is varied from 0 to $100 \mathrm{Mbps}$ and when the datagram size is $1470 \mathrm{~B}$. Also indicated are the $95 \%$ confidence interval. It can be seen that when the data generation rate is progressively increased the power consumption is also increases. The result clearly shows the linear relationship between ONU power consumption and access data rate. The highest power was consumed for $100 \mathrm{Mbps}$ access data rate which is $11.72 \mathrm{~W}$. Let the data generation rate [Mbps] be the independent variable $x$, while the measured power consumption [W] is response $y$. Then the coefficients of the linear model are; $\gamma_{o}(\mathrm{~W})$ which represents the intercept and $\alpha_{o}$ (Ws) which represents the slope of the line. These coefficients value was calculated by using Matlab software in which we obtained the value of $\gamma_{o}=11.51$ and $\alpha_{o}=$ 0.00208 . Therefore, the ONU power consumption can be modeled as:

$$
P_{\text {ONU }}=11.51+0.00208 r_{o}
$$

According to this figure, we are able to model the linear power consumption model by considering the instantaneous power consumption of the ONU versus traffic load. When the traffic load increases, there will be a linear increase of the instantaneous ONU power consumption and vice versa. It can also be found that the power consumed during idle mode dominate the overall power consumed by the ONU. Yet, even when there is a low traffic load, the proposed linear model ensures some fixed amount of power consumption. Therefore, we propose linear model consisting of two components; fixed, which is independent of the traffic load, and variable, which is proportional to the traffic load. The power consumption model of the ONU can be expressed as:

$$
P_{\text {ONU }}(r)=\gamma_{o}+\alpha_{o} \cdot r_{o}
$$

where $\gamma_{o}$ is the power consumption of ONU when there is no traffic load, i.e. in idle mode, $\alpha_{o}$ is the energy consumed by the ONU to transmit one bit of information and $r_{o}$ is the average access data rate per ONU.

This linear model corresponds to the particular ONU technology and ONUs of different technologies, manufacturers, production years or configurations might have different linear models. Since real testbed measurement was utilized in order to obtain the proposed model, it is acceptable to express the relationship between instantaneous power consumption and traffic load as a linear power consumption model. This reasoning gives full confidence for the usage of a linear model in future studies focused on improving the energy efficiency of already installed optical access equipment.

\subsection{Model Validation}

In order to validate our power consumption model, the comparison have been done with previously reported work [21] in which a generic power consumption model for the CPE that can be applied for both optical and wireless devices have been presented. The power consumption model is expressed as:

$$
P_{C P E}=P_{\text {idle }}+\frac{P_{\max }-P_{\text {idle }}}{C_{\max }} C
$$

Where $P_{C P E}, P_{\text {idle }}$ and $P_{\max }$ are the power consumption of CPE, power consumption in idle mode and power consumption at maximum load, respectively, $C_{\max }$ is the maximum load and $C$ is the instantaneous load. $P_{\text {idle }}$ is dependent on the device technologies in which in this analysis, the value was set equal to $11.51 \mathrm{~W}$ for both models to represent the comparison between the same model of ONU device. The result of the comparison between our proposed model and model presented in [21] can be found in Figure 4.

Figure 4 depicts the comparison of power consumption model between our work and [21] versus data rate that was varied from 0 to $1 \mathrm{Gbps}$. As can be seen in Figure 4, our model shows a similar trend with [21] thus proves the validity of the proposed model. In other words, the proposed linear power consumption model can be acceptable to represent the power consumption trend of the ONU. It can also be found that the model by [21] achieve higher power consumption compared to the proposed model. This is because the product of the second term on the right hand side in Equation (3) is higher than the proposed model as expressed in Equation (1) which resulting in higher power consumption. 


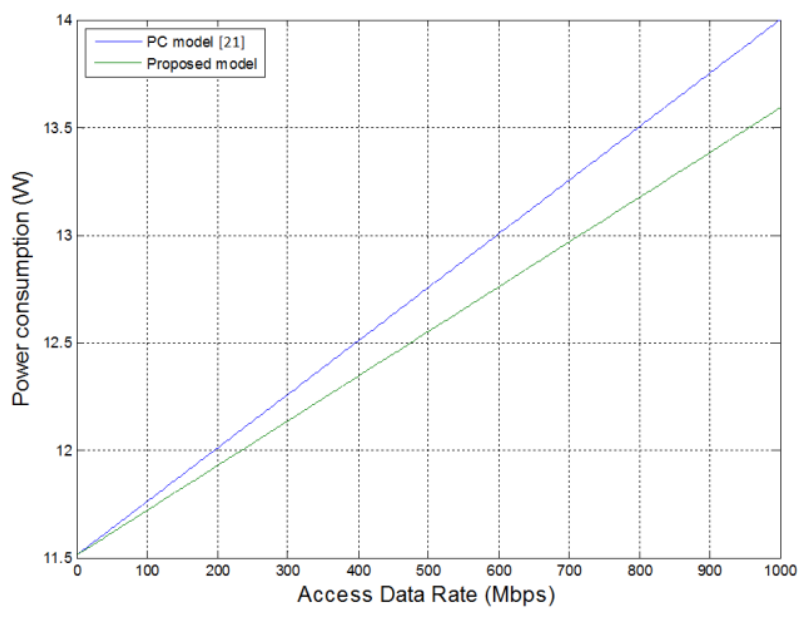

Figure 4 Comparison of our proposed model with theoretical model presented in [21]

From this comparison, it was also able to prove that our model is suitable to be used for data rates up to 1 Gbps. As have been mentioned previously, our measurement does not able to measure the power consumption of the ONU for data rate above 100 Mbps due to the limitation of the power measurement tool. However, based on the results presented in Figure 4, it was shown that our model can be used for data rates up to 1 Gbps by taking full advantage of the high capacity offered by the GPON network. In order to further prove the usability of our model, a comparison was done between our model when it operates at GPON data rates of 1 Gbps and the power consumption values obtained by averaging the power consumption from manufacturer's datasheets and previous related works ranging from $7 \mathrm{~W}$ to $17 \mathrm{~W}$. It was found that, our model have a power consumption of $13.59 \mathrm{~W}$ while the power consumption for the latter is $11.22 \mathrm{~W}$. It shows that our model has slightly higher power consumption but the small difference of approximately $19 \%$ between our model and averaged value of power consumption shows that our model is acceptable.

\subsection{CONCLUSION}

In this paper, we provide a theoretical linear power consumption model of an ONU as a function of traffic load. Then, we perform an experimental measurement and investigate the impact of traffic intensity on the power consumption of ONU. Analysis has been performed on a GPON network testbed containing commercially available OLT, passive splitter and ONU. The developed Arduino-based power monitoring tool has been utilized to measure the real time power consumption of the ONU. The measurement results are consistent with the proposed model. Therefore, linear power consumption model can be accepted as a model for precise expression of the interdependence between instantaneous ONU power consumption and traffic load. Due to a limitation in the sampling rate and precision of the measurement device used in the experiment, the measurement is limited to a maximum data rate of $100 \mathrm{Mbps}$. Comparison have been done to validate our proposed power consumption model and in the same time further proving that our model is applicable for up to $1 \mathrm{Gbps}$ access data rate. The power consumption modeling for the optical access integrated with wireless network will be considered in our future work as this network has a potential to provide high capacity as well as mobility.

\section{Acknowledgement}

This work is supported by Ministry of Higher Education under the SLAl scheme. We greatly appreciate Universiti Teknologi Malaysia and Photonics Characterization Laboratory for providing the facilities which enabled this work to be accomplished. We would also like to thank the MoHE for sponsoring this work under FRGS fund vote number 4F961.

\section{References}

[1] W. Van Heddeghem, S. Lambert, B. Lannoo, D. Colle, M. Pickavet, and P. Demeester. 2014. Trends in Worldwide ICT Electricity Consumption from 2007 to 2012. Comput. Commun. 50: 64-76.

[2] C. Lange and A. Gladisch. 2010. Energy Efficiency Limits of Load Adaptive Networks. Optical Fiber Communication (OFC), collocated National Fiber Optic Engineers Conference, 2010 Conference on (OFC/NFOEC). 1: 2-4.

[3] J. Baliga, R. Ayre, K. Hinton, and R. S. Tucker. 201 1. Energy Consumption in Wired and Wireless Access Networks. IEEE Communication Magazine: Energy Efficiency in Communications. June: 70-77.

[4] J. Kani. 2013. Power Saving Techniques and Mechanisms for Optical Access Networks Systems. J. Light. Technol. 31 (4): 563-570.

[5] Y. Yan, S.-W. Wong, L. Valcarenghi, S.-H. Yen, D. Campelo, S. Yamashita, L. Kazovsky, and L. Dittmann. 2010. Energy Management Mechanism for Ethernet Passive Optical Networks (EPONs). Communications (ICC), 2010 IEEE International Conference on. 1-5.

[6] A. Dixit, B. Lannoo, D. Colle, M. Pickavet, and P. Demeester. 2012. ONU Power Saving Modes in Next Generation Optical Access Networks: Progress, Efficiency and Challenges. Opt. Express. 20(26).

[7] R. Coomonte, C. Lastres, C. Feijóo, and Á. Martín. 2012. A Simplified Energy Consumption Model for Fiber-based Next Generation Access Networks. Telemat. Informatics. 29(4): 375-386.

[8] A. Gladisch, C. Lange, and R. Leppla. 2008. Power Efficiency of Optical Versus Electronic Access Networks. 34th European Conference on Optical Communication. 2(September): 143-146.

[9] M. Tadokoro, T. Shinagawa, H. Ujikawa, H. Nomura, T. Fujiwara, M. Akimoto, and T. Shibata. 2014. Power-saving Technologies for Network Equipment and their Application-ONU/wireless-LAN Sleep Technologies. NTT Technical Review. 12(3).

[10] A. Ramli, M. A. Wong, N. Zulkifli, and S. M. Idrus. 2015 Integrated Optical and Wireless Access Networks: from 
the Energy Consumption Perspective. ARPN J. Eng. Appl. Sci. 10(18): 8485-8490.

[11] L. Valcarenghi, D. P. Van, P. Castoldi, S. Superiore, and S. Anna. 2011. How to Save Energy in Passive Optical Networks. 13th International Conference on Transparent Optical Networks. 1-5.

[12] D. Schien, V. C. Coroama, L. M. Hilty, and C. Preist. 2015. The Energy Intensity of the Internet: Edge and Core Networks. Adv. Intell. Syst. Comput. 310(August): 157-170.

[13] J. Lorincz, T. Garma, and G. Petrovic. 2012. Measurements and Modelling of Base Station Power Consumption under Real Traffic Loads. Sensors. 12: 4281-4310.

[14] R. Lent. 2010. Simulating the Power Consumption of Computer Networks. 2010 15th IEEE International Workshop on Computer Aided Modeling, Analysis and Design of Communication Links and Networks, CAMAD 2010. 96-100.

[15] L. Chiaraviglio, D. Ciullo, M. Mellia, and M. Meo. 2013. Modeling Sleep Mode Gains in Energy-aware Networks. Comput. Networks. 57(15): 3051-3066.

[16] K. Gomez, D. Bory, R. Riggio, T. Rasheed, D. Miorandi, and F. Granelli. 2012. Measurement-based Modelling of Power
Consumption at Wireless Access Network Gateways. Comput. Networks. 56(10): 2506-2521.

[17] S. D. Skubic Björn, Einar In de Betou, Tolga Ayhan. 2012. Energy-Efficient Next-Generation Optical Access Networks. IEEE Communications Magazine: Topics in Optical Communication. January: 122-127.

[18] S. Lambert, B. Lannoo, D. Colle, M. Pickavet, J. Montalvo, J. A. Torrijos, P. Vetter, and M. Hill. 2013. Power Consumption Evaluation for Next-Generation Passive Optical Networks. 24th Tyrrhenian International Workshop on Digital Communications. 1-4.

[19] S. Aleksić and A. Lovrić. 2010. Power Efficiency in Wired Access Networks. Elektrotechnik und Informationstechnik, 127(November): 321-326.

[20] "iPerf - The TCP, UDP and SCTP network bandwidth measurement tool." [Online]. Available: https://github.com/esnet/iperf.

[21] C. Gray, R. Ayre, K. Hinton, and R. S. Tucker. 2015. Power Consumption of loT Access Network Technologies. 2015 IEEE International Conference on Communication Workshop (ICCW). 2818-2823. 